\title{
Spatial Growth and Instability Analysis of Area, Production and Yield of Sugarcane in India
}

\author{
Bhim Singh ${ }^{1 *}$, Prerna Sharma ${ }^{1}$, C.K. Arya ${ }^{2}$, Amar Singh $^{3}$ and Jitendra Kumar ${ }^{4}$ \\ ${ }^{1}$ Department of Basic Science, College of Agriculture, Sardar Vallabhbhai Patel University of Agriculture and Technology, Meerut, \\ (U.P.), India \\ ${ }^{2}$ College of Horticulture and Forestry (AU, Kota), Jhalawar, Rajasthan, India \\ ${ }^{3}$ Department of Agricultural Statistics, CSSS PG College, Machhra, Meerut, (U.P.) India \\ ${ }^{4}$ Department of Statistics, Central University of Rajasthan, Bandarsindri, NH-8, Kishangarh, District: Ajmer, Rajasthan, India
}

*Corresponding author: bhimsingh1@gmail.com (ORCID ID: 0000-0001-8016-8361)

Received: $12-03-2021$

Revised: 23-05-2021

Accepted: 05-06-2021

\begin{abstract}
In the present study, spatial compound growth rates were estimated to know the growth pattern and instability in the area, production, and productivity of sugarcane in major sugarcane growing states of India. A secondary time series data of major sugarcane producing states of India like Uttar Pradesh, Maharashtra, Karnataka, Tamil Nadu, Bihar, Andhra Pradesh, Haryana, Gujarat, Punjab, Madhya Pradesh, and Odisha for the period thirty years from 1990-91 to 2019-20 have been utilized for the present study. The compound growth rates were computed with the help of exponential function, and instability/ variability has been computed by using techniques of co-efficient of variation and Cuddy Della-Valle Index method. Student's t-test was applied to check the significant differences in area, production, and productivity trends using compound growth rates (CGR). CGR of sugarcane production was 1.13 per centpercent in India during the study period with a significant growth rate in area (1.12\%) and yield $(0.39 \%)$. The statistically significant instability in sugarcane production was high at 9.67 percent than area $(7.20 \%)$ and yield (5.26\%) in the study period. The state-wise compound growth rate of sugarcane production was positively significant in Madhya Pradesh (5.31\%), Bihar (3.65\%), Maharashtra (3.39\%), Karnataka (1.42\%), and Uttar Pradesh (1.36\%). The highest negative growth rate was observed in Odisha $(-5.45 \%)$ and Andhra Pradesh (-1.63\%). The instability of sugarcane production was highest at 44.06 percent than area $(36.66 \%)$ in Odisha and yield (14.80\%) in Madhya Pradesh.

\section{Highlights}

(0 The growth of the area, production and yield of sugarcane are improved in India.

- Sugarcane plays a crucial role to fulfill the national food security mission for commercial crops.
\end{abstract}

Keywords: Compound growth rate, Cuddy Della-Valle index, spatial growth, sugarcane

Sugarcane (Saccharum officinarum L.) is one of the important cash crops of India. There is less risk in sugarcane cultivation, and it provides assured returns to the farmers even in adverse conditions (Raju and Kumar, 219). Cultivation of sugarcane was comprehensive to all or any tropical and subtropical regions. Sugarcane can be a leading resource for sugar manufacture and other associated groups of industries. Sugarcane has taken an essential responsibility for food security, nutrition, and socio- financial improvement of the farming community (Rahman and Bee, 2019). Sugarcane is a flexible crop being a premier source of food, fiber, fodder, fuel, and chemicals such as ethanol (Yadav et al. 2006). Sugarcane is an annual crop and requires 10-15 and

How to cite this article: Singh, B., Sharma, P., Arya, C.K., Singh, A. and Kumar, J. (2021). Spatial Growth and Instability Analysis of Area, Production and Yield of Sugarcane in India. Economic Affairs, 66(2): 245-252.

Source of Support: None; Conflict of Interest: None 
even 18 months to mature. In India, sugarcane is grown in tropical states, namely Andhra Pradesh, Gujarat, Karnataka, Madhya Pradesh, Maharashtra, Odisha, and Tamil Nadu sub-tropical states such as Bihar, Haryana, Punjab, and Uttar Pradesh. India is the world's second-biggest sugar producer after Brazil, and its production is expected to boom greater increasingly, partially stimulated with the aid of using renewed public assist to the sub-sector (FAO, 2019) and produces about 20\% of the world's sugarcane (Medar et al. 2019). In India, major sugarcane producer states were Uttar Pradesh, Maharashtra, Karnataka, Tamil Nadu, Bihar, Andhra Pradesh, Haryana, Gujarat, Punjab, Madhya Pradesh, and Odisha, where more than $96 \%$ of sugarcane production comes from these eleven states. In India, sugarcane occupies 5.11 million hectares, production of 5.11 million hectares, producing 400.16 million tons, and productivity of 78.25 tonnes per hectare (Anonymous, 2020). The present study deals with the spatial growth and instability analysis of the area, production, and yield of sugarcane in India. The study will be helpful for policymakers in the field of sugarcane and its related developments.

\section{DATA AND METHODOLOGY}

The statistic data related to the area, production, and yield of sugarcane for 30 years (1990-91 to 2019-20) were used for the present study. The data for the study were obtained from secondary sources of India and stated Uttar Pradesh, Maharashtra, Karnataka, Tamil Nadu, Bihar, Andhra Pradesh, Haryana, Gujarat, Punjab, Madhya Pradesh and Odisha considered as the top leading sugarcane producing states in India. More than $96 \%$ of total sugarcane production comes from these top eleven states (Table 1). To analyze the spatial growth and instability in area, production and yield of sugarcane crops, secondary time series data were obtained from ICAR-Sugarcane Breeding Institute, Coimbatore for time period 1990-91 to 2019-20. Data was analyzed using various statistical tools and techniques such as mean, compound growth rate (CGR), student's t-test, coefficient of variance (CV), Cuddy Della-Valle Index (CDI) and Coppock's Instability Index (CII).

\section{Compound growth rate (CGR) analysis}

The following equation was used for estimation of compound growth rates (CGRs) of area, production, and yield of sugarcane crops:

$$
Y=a b^{t}
$$

where, $Y=$ dependent variable for which growth rate is to be estimated, $t=$ time variable in year (1, $2, \ldots, 30), a$ (intercept) and $b$ (regression coefficient) are unknown constants to be estimated with the help of the principle of the least square method by changing the equation into logarithmic form as:

$$
\log Y_{t}=\log a+t \log b
$$

Moreover, now, compound growth rate (CGR) was calculated in percent as:

$$
C G R(r)=(b-1) \times 100
$$

where $r$ is the compound growth rate.

The significance of the estimated compound growth rate (CGR) in the area, production and yield will be tested with the help of student's t-test by the following formula:

$$
t=\frac{b}{S E(b)}
$$

\section{Instability analysis of sugarcane}

It is well-known that high growth and low instability in production are prerequisites for sustainable agricultural performance (Snehdeep et al. 2017). It has been a great concern that technological change in sugarcane production has increased variability, which is considered to be one of the important facts. The instability in the time series data can be estimated by different methods, like the coefficient of variation, Cuddy Della-Valle Index, Coppock instability index, etc. Coefficient of variation (CV) is one of the prevalent methods for estimating the instability in time series data. The coefficient of variation is expressed in percentage and is calculated as follows:

Coefficient of Variation $=\frac{\text { Standard Deviation }}{\text { Mean }} \times 100 \ldots$

The instability measured by coefficient of variation has limitations of overestimation (Cuddy and 
Della-Valle, 1978). To overcome the problem of overestimation of CV, Cuddy and Della-Valle (1978) have been revised the $\mathrm{CV}$ by applying a coefficient of determination $\left(\mathrm{R}^{2}\right)$ referred Cuddy and DellaValle Index (CDI) as follows:

$\mathrm{CDI}=$ Coefficient of variation $\times\left(1-\mathrm{R}^{2}\right)^{1 / 2}$

where, $\mathrm{R}^{2}$ is the adjusted coefficient of determination that takes into account the number of variables in a data set.

\section{Coppock's Instability Index (CII)}

According to Coppock (1962) and Rai and Sarup (1989), Coppock's Instability Index (CII) were estimated as follow:

$$
\mathrm{CII}=(\operatorname{Antilog}(\sqrt{V \log -1}) \times 100)
$$

where,

$$
\mathrm{V} \log =\frac{1}{n-1} \Sigma\left(\log \frac{Y_{t+1}}{Y_{t}}-m\right)^{2}
$$

$\mathrm{Yt}=$ the time series variable under consideration (production/area/yield) for the $i^{\text {th }}$ year $(i=1,2,3$, $\ldots, n)$

$m=$ Arithmetic mean of the difference between the $\operatorname{logs}$ of $Y_{\mathrm{t}+1^{\prime}}, Y_{t^{\prime}}$ etc.,

$\mathrm{V} \log =$ Logarithmic variance of the series.
Cuddy Della-Valle (Cuddy and Della-Valle, 1978) Index was preferred by several researchers (Deb and Pramanik, 2015; Dudhat et al. 2017; Senapati and Goyari, 2018; Nimbrayan et al. 2019) for estimating the instability in time series data because CDI method first de-trends the given time series data and provide a clear direction of instability. Thus, in the present article, we have estimated the instability based on Cuddy Della-Valle index. The values of Cuddy Della-Valle index can observe instability intensity. The ranges of Cuddy Della-Valle index (CDI) have been described by Sihmar (2014). Accordingly, there are three kinds of CDI in time series data depending on the value of CDI. If the value of CDI in the time series is less than 15 , then it will be comes under the category of low instability if the value of CDI is more than 15 and less than 30 , then medium instability, and if more than 30 , there will be high instability.

\section{RESULTS AND DISCUSSION}

In the present study, efforts have been made to measure spatial growth and instability analysis of area, production, and yield of India's major significant sugarcane growing states. The compound growth rates have been worked out to measure the growth performance of sugarcane crops state-wise for the period of the last thirty years from 1990-91 to 2019-20. CV, CDI and CII were calculated to measure the instability in area, production, and yield, but instability was discussed with the help of CDI.

Table 1: Area, production and yield of sugarcane in major states of India, 2019-20

\begin{tabular}{llll}
\hline State & $\begin{array}{l}\text { Area } \\
\text { (“000“ } \mathbf{h a )}\end{array}$ & $\begin{array}{l}\text { Production } \\
\text { (“000“价nes) }\end{array}$ & $\begin{array}{l}\text { Yield } \\
\text { (tonnes/ha) }\end{array}$ \\
\hline Uttar Pradesh & 2151 & 173816 & 80.81 \\
Maharashtra & 979 & 73090 & 74.65 \\
Karnataka & 451 & 40612 & 90.00 \\
Tamil Nadu & 206 & 20600 & 100.00 \\
Bihar & 233 & 12833 & 55.08 \\
Andhra Pradesh & 126 & 9593 & 76.14 \\
Haryana & 118 & 9484 & 80.65 \\
Gujarat & 153 & 9198 & 60.00 \\
Punjab & 96 & 7896 & 82.25 \\
Madhya Pradesh & 118 & 5733 & 48.59 \\
Odisha & 2 & 141 & 59.92 \\
Major 11 States & $4633(95.19)$ & $362996(96.31)$ & 73.46 \\
India & 4867 & 376905 & 77.6 \\
\hline
\end{tabular}

Source: Cooperative Sugar Vol.51 (5) Jan, 2020 (Provisional). 
Table 2: Area, production and yield of sugarcane in India, 1990-91 to 2019-20

\begin{tabular}{llll}
\hline Triennium Ending & $\begin{array}{l}\text { Area } \\
\text { ('000 ha) }\end{array}$ & $\begin{array}{l}\text { Production } \\
\text { (million tonnes) }\end{array}$ & $\begin{array}{l}\text { Yield } \\
\text { (tonnes/ha) }\end{array}$ \\
\hline $1990-91$ & 3686 & 241.05 & 65.40 \\
$2000-01$ & 4316 & 295.96 & 68.60 \\
$2010-11$ & 4886 & 342.38 & 70.10 \\
$2019-20$ & 4867 & 376.91 & 77.60 \\
\hline
\end{tabular}

Source: Cooperative Sugar Vol.51 (5) Jan, 2020 (Provisional).

Table 3: Trends in area, production and yield of sugarcane in major states of India from 1990-91 to 2019-20

\begin{tabular}{|c|c|c|c|c|c|c|c|c|c|c|c|c|}
\hline \multirow[b]{2}{*}{ State } & \multicolumn{4}{|c|}{ Area } & \multicolumn{4}{|c|}{ Production } & \multicolumn{4}{|c|}{ Yield } \\
\hline & $\begin{array}{l}\text { Mean } \\
\text { (‘000’ ha.) }\end{array}$ & $\begin{array}{l}\text { CV } \\
(\%)\end{array}$ & $\begin{array}{l}\text { CDI } \\
(\%)\end{array}$ & $\begin{array}{l}\text { CGR } \\
(\%)\end{array}$ & $\begin{array}{l}\text { Mean } \\
\text { ('000’ tons) }\end{array}$ & $\begin{array}{l}\text { CV } \\
(\%)\end{array}$ & $\begin{array}{l}\text { CDI } \\
(\%)\end{array}$ & $\begin{array}{l}\text { CGR } \\
(\%)\end{array}$ & $\begin{array}{l}\text { Mean } \\
\text { (tons/ha) }\end{array}$ & CV $(\%)$ & $\begin{array}{l}\text { CDI } \\
(\%)\end{array}$ & $\begin{array}{l}\text { CGR } \\
(\%)\end{array}$ \\
\hline Uttar Pradesh & 2052.00 & 6.75 & 4.04 & $0.63^{* * *}$ & 126201.83 & 16.13 & 9.80 & $1.36^{* * *}$ & 61.31 & 11.68 & 9.55 & $0.73^{* * *}$ \\
\hline Maharashtra & 703.20 & 36.41 & 22.66 & $3.44^{* * *}$ & 56252.50 & 38.13 & 27.19 & $3.39^{* * *}$ & 79.56 & 9.75 & 9.92 & $-0.04^{\mathrm{NS}}$ \\
\hline Karnataka & 350.43 & 23.05 & 19.59 & $1.54^{* * *}$ & 30461.67 & 26.9 & 24.83 & $1.42^{* *}$ & 86.35 & 9.67 & 9.78 & $-0.13^{\mathrm{NS}}$ \\
\hline Tamil Nadu & 279.57 & 20.53 & 20.55 & $-0.45^{\mathrm{NS}}$ & 29002.97 & 23.58 & 23.32 & $-0.69^{\mathrm{NS}}$ & 103.07 & 5.54 & 5.24 & $-0.24^{* *}$ \\
\hline Bihar & 160.47 & 37.85 & 28.26 & $2.86^{* * *}$ & 7688.73 & 49.33 & 37.39 & $3.65^{* * *}$ & 46.45 & 14.93 & 13.98 & $0.75^{* *}$ \\
\hline Andhra Pradesh & 186.97 & 23.48 & 18.87 & $-1.85^{* * *}$ & 14308.97 & 25.08 & 21.69 & $-1.63^{* * *}$ & 76.46 & 5.46 & 5.19 & $0.23^{*}$ \\
\hline Haryana & 124.37 & 21.89 & 17.15 & $-1.63^{* * *}$ & 7751.13 & 15.58 & 15.86 & $-0.00^{\mathrm{NS}}$ & 63.91 & 16.58 & 8.32 & $1.65^{* * *}$ \\
\hline Gujarat & 174.77 & 16.04 & 14.54 & $0.88^{* *}$ & 12544.23 & 13.6 & 13.43 & $0.38^{\mathrm{NS}}$ & 72.33 & 8.75 & 7.60 & $-0.50^{* * *}$ \\
\hline Punjab & 102.17 & 24.53 & 22.76 & $-1.08^{* *}$ & 6660.60 & 24.37 & 24.79 & $-0.08^{\mathrm{NS}}$ & 65.88 & 13.09 & 10.14 & $0.93^{* * *}$ \\
\hline Madhya Pradesh & 64.50 & 38.16 & 18.42 & $3.62^{* * *}$ & 2763.40 & 54.83 & 20.18 & $5.31^{* * *}$ & 41.03 & 19.23 & 14.80 & $1.62^{* * *}$ \\
\hline Odisha & 17.07 & 59.93 & 36.66 & $-5.86^{* * *}$ & 1054.50 & 66.11 & 44.06 & $-5.46^{* * *}$ & 61.42 & 9.45 & 9.00 & $0.39^{*}$ \\
\hline India & 4393.97 & 11.96 & 7.20 & $1.12^{* * *}$ & 300442.00 & 14.73 & 9.67 & $1.31^{* * *}$ & 69.05 & 6.24 & 5.26 & $0.39^{* * *}$ \\
\hline
\end{tabular}

*: Significant @ 10 \% level of significance, ${ }^{* *}$ : Significant @ 5 \% level of significance, ${ }^{* * *}$ : Significant @ 1 \% level of significance and NS: Nonsignificant.

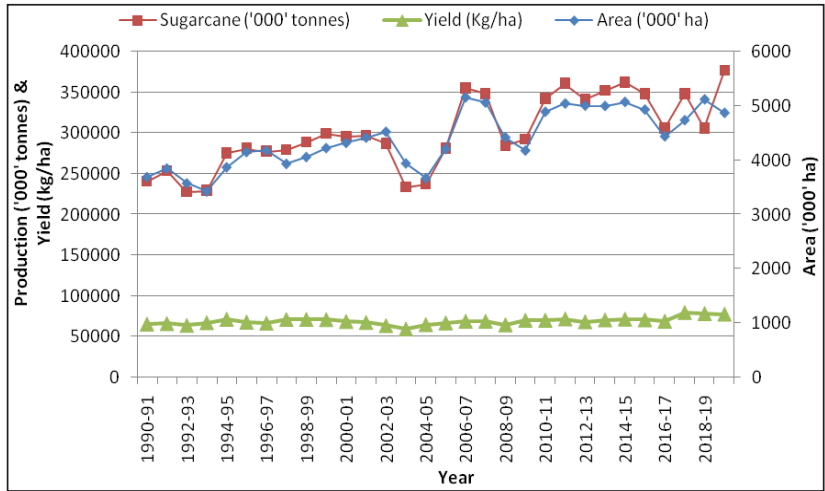

Fig. 1: Trend of Area, Production and yield of sugarcane in India, 1990-91 to 2019-20

\section{Present scenario of sugarcane in major producing states}

Detail regarding the state-wise area, production, and yield of sugarcane in major states of India 201920 is given in Table 1. Important sugarcane growing states are Uttar Pradesh, Maharashtra, Karnataka, Tamil Nadu, Bihar, Andhra Pradesh, Haryana, Gujarat, Punjab, Madhya Pradesh, and Odisha.

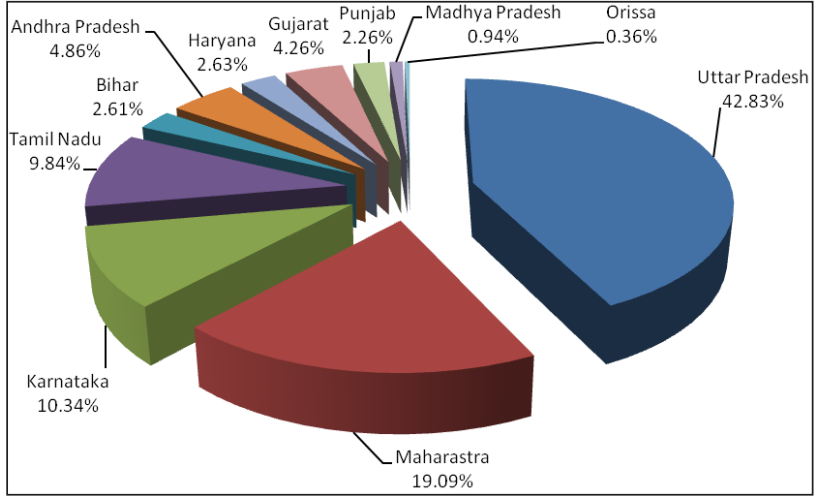

Fig. 2: State wise contribution of sugarcane production, 1990-91 to $2019-20$

Among these states, the known fact is that Uttar Pradesh state ranks first in terms of production and area cultivation during 2019-20. Thus, Uttar Pradesh is the leader among all sugarcane producing states with more than 42 percent (Fig. 2) contribution in India's sugarcane production with 126.20 lakh tonnes (Table 3). The total area in which sugarcane is produced in Uttar Pradesh is 2151 thousand hectares 


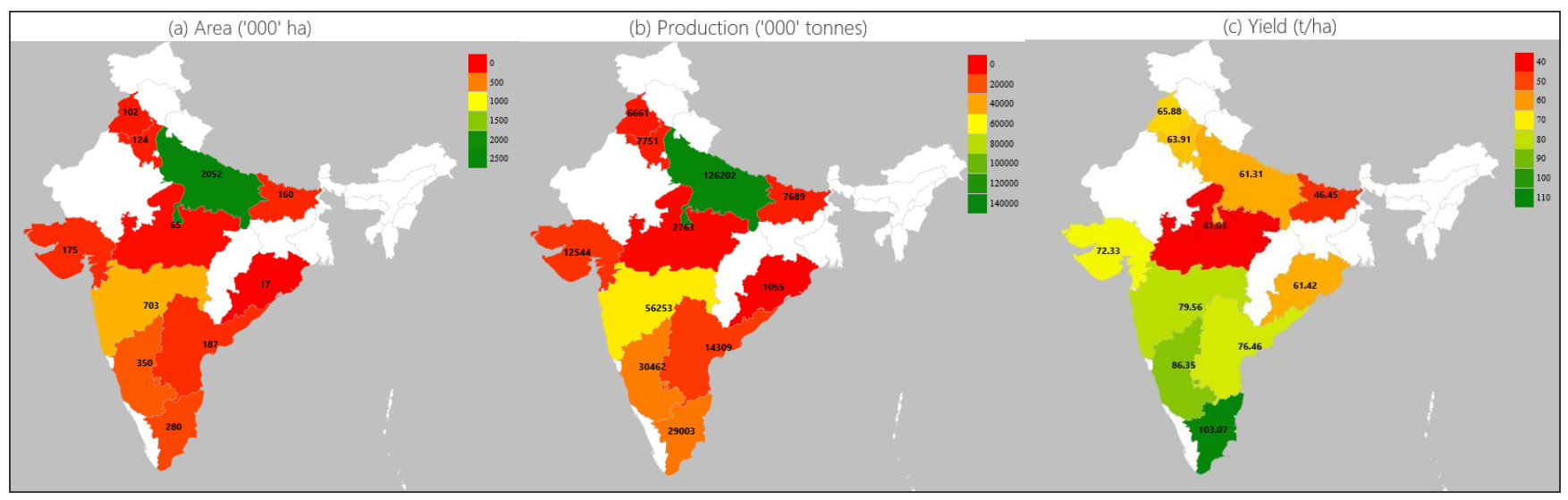

Fig. 3: Spatial distribution of average area, production and yield of sugarcane in major states of India, 1990-91 to 2019-20

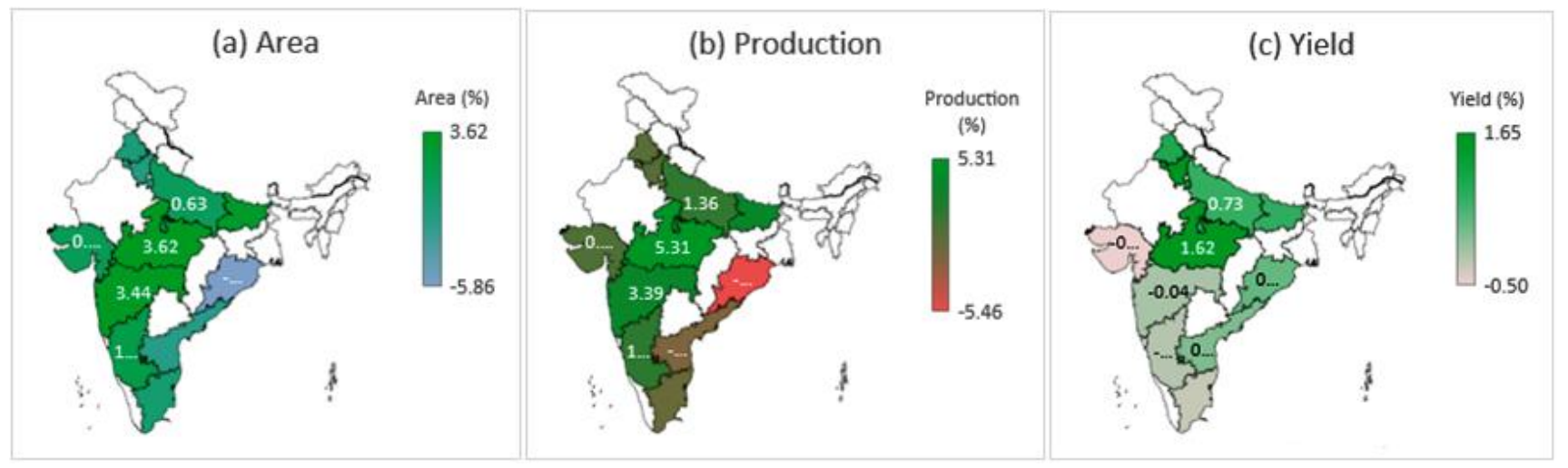

Fig. 4: Spatial CGR of area, production and yield of sugarcane in major states of India, 1990-91 to 2019-20

with production (173.82 million tonnes) and productivity (80.81 tonnes/ha) (Table 1). Moreover, Uttar Pradesh ranks fourth in sugarcane yield compared to all other states in India. In India, the highest sugarcane yield was found in Tamil Nadu (100.00 tonnes per ha) against all India average of 77.6 tonnes per ha, followed by Karnataka (90.00 tonnes per ha) and Punjab (82.25 tonnes per ha). The highest average area (2052 thousand ha) and production (126201.83 thousand tonnes) were observed in Uttar Pradesh (Fig. 2. and Table 3). Highest sugarcane yield was observed in Tamil Nadu (Fig. 3). The spatial distribution of average area, production and yield of sugarcane in major states of India during the study period was given in Fig. 4.

\section{Growth and instability of sugarcane in major producing states}

The area and production of sugarcane in important producing states, namely Uttar Pradesh, Maharashtra, Karnataka, Bihar, Gujarat, and Madhya
Pradesh, were included Uttar Pradesh, Maharashtra, Karnataka, Bihar, Gujarat, and Madhya Pradesh, increased significantly over time in the study period. The highest significant growth rate in the sugarcane yield was recorded as 1.65 percent in the Haryana. State-wise highest growth rate of sugarcane production was positive and statistically significant@1\% level of significance in Madhya Pradesh (5.31\%), Bihar (3.65\%), Maharashtra $(3.39 \%)$, Karnataka $(1.42 \%)$, and Uttar Pradesh $(1.36 \%)$. Highest negative growth rate was observed in Odisha (-5.46\%), and Andhra Pradesh (-1.63\%) whereas non-significant growth was recorded in Tamil Nadu, Haryana, Gujarat and Punjab (Table 3 and Fig. 3). There was the highest significant growth of area $(3.62 \%)$, and production $(5.31 \%)$ of sugarcane in Madhya Pradesh whereas lowest negative significant growth in the area $(-5.86 \%)$ and production $(-5.46 \%)$ was observed in Odisha during the study period 1990-91 to 2019-20. The statistically significant instability of Odisha in production was high at 44.06 percent than the area 
Table 4: Growth in area, production and yield of sugarcane in India, 1990-91 to 2019-20

\begin{tabular}{|c|c|c|c|c|c|c|c|c|c|c|c|c|}
\hline \multirow[b]{2}{*}{ Period } & \multicolumn{4}{|c|}{ Area } & \multicolumn{4}{|c|}{ Production } & \multicolumn{4}{|c|}{ Yield } \\
\hline & $\begin{array}{l}\text { Mean } \\
\text { (‘000' ha.) }\end{array}$ & $\begin{array}{l}\mathrm{CV} \\
(\%)\end{array}$ & $\begin{array}{l}\text { CDI } \\
(\%)\end{array}$ & $\begin{array}{l}\text { CGR } \\
(\%)\end{array}$ & $\begin{array}{l}\text { Mean } \\
\text { (million tons) }\end{array}$ & $\begin{array}{l}\mathrm{CV} \\
(\%)\end{array}$ & $\begin{array}{l}\text { CDI } \\
(\%)\end{array}$ & $\begin{array}{l}\text { CGR } \\
(\%)\end{array}$ & $\begin{array}{l}\text { Mean } \\
\text { (tons/ha) }\end{array}$ & $\begin{array}{l}\text { CV } \\
(\%)\end{array}$ & $\begin{array}{l}\text { CDI } \\
(\%)\end{array}$ & $\begin{array}{l}\text { CGR } \\
(\%)\end{array}$ \\
\hline Period I (1990-1999) & 3891.70 & 6.90 & 5.11 & $1.67^{* *}$ & 265.45 & 9.55 & 5.56 & $2.74^{* *+1+}$ & 68.12 & 4.10 & 2.80 & $1.04^{* * *}$ \\
\hline Period II (2000-2009) & 4384.40 & 10.37 & 10.74 & $0.74^{\mathrm{NS}}$ & 291.37 & 13.45 & 13.73 & $1.21^{\mathrm{NS}}$ & 66.31 & 4.90 & 4.99 & $0.47^{\mathrm{NS}}$ \\
\hline Period III (2010-2019) & 4905.80 & 4.06 & 4.16 & $-0.356^{\mathrm{NS}}$ & 344.50 & 6.63 & 6.93 & $-0.39^{\mathrm{NS}}$ & 72.73 & 5.69 & 4.13 & $1.36^{* *}$ \\
\hline Period IV (1990-2020) & 4393.97 & 11.96 & 7.20 & $1.12^{* * *}$ & 300.44 & 14.73 & 9.67 & $1.31^{* * *}$ & 69.05 & 6.24 & 5.26 & $0.39^{* * * *}$ \\
\hline
\end{tabular}

*: Significant @ 10 \% level of significance, ${ }^{* *}$ : Significant @ 5 \% level of significance, ${ }^{* * *}$ : Significant @ 1 \% level of significance and NS: Nonsignificant.

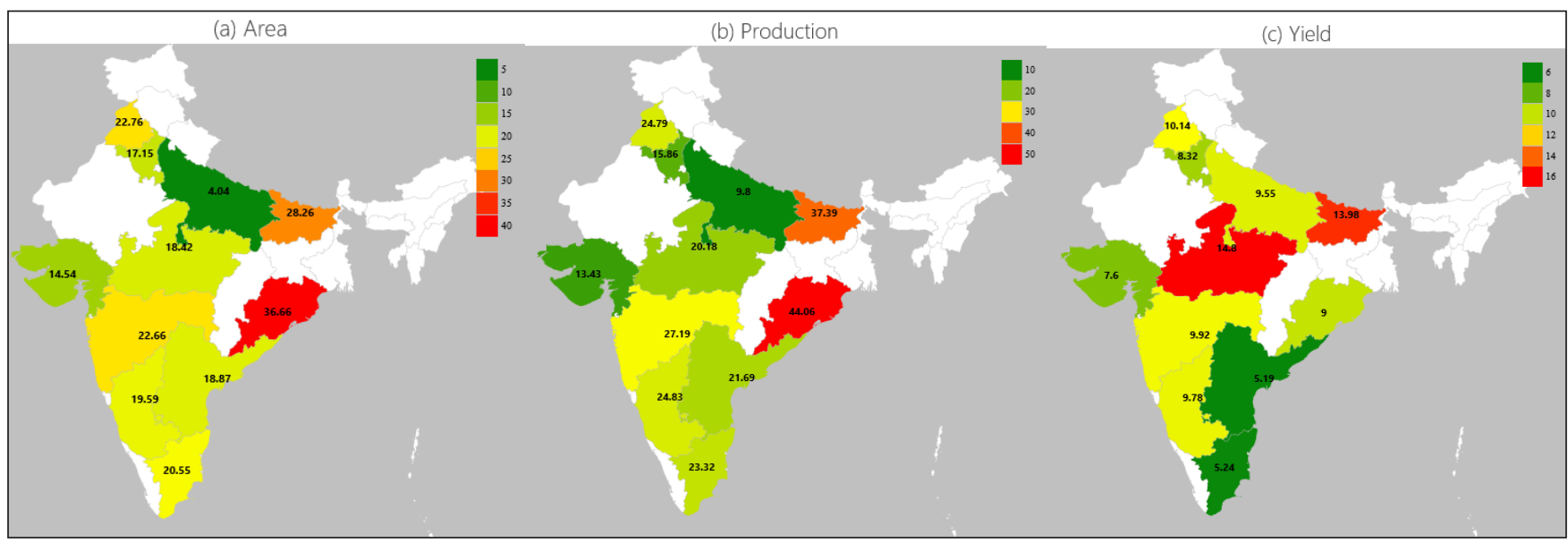

Fig. 5: Spatial instability of area, production and yield of sugarcane in major states of India during 1990-91 to 2019-20

(36.66\%) and yield (14.80\%) of Madhya Pradesh. The highest significant instability in the area as 36.66 was observed in Odisha followed by Bihar (28.26\%), Punjab (22.76\%). In contrast, the lowest instability in the area (4.04\%) and production (9.80) was observed in Uttar Pradesh among all the states (Fig. 5). Also, the lowest instability in the yield (5.19\%) was recorded in Andhra Pradesh (Table 3). Uttar Pradesh and Gujarat have recorded the lowest instability in the area and production, whereas Maharashtra, Karnataka, Tamil Nadu, Bihar, Andhra Pradesh, Haryana, Punjab, and Madhya Pradesh comes under the medium instability and Odisha have only one state which showed high instability in the study period. On the side of yield, all the states have shown low instability. Thus, instability was high for production and area than yield in all significant sugarcane producing states. However, the population is growing continuously along with the production of sugarcane is successful to meet the necessities of the utilization of sugarcane in India. It is clear that the high production of sugarcane creates full sufficient food security and the Indian economy.

\section{Trends in area, production and yield of sugarcane in India}

The area under sugarcane cultivation in India was moderately accelerated from 3686 thousand hectares during triennium ending (TE) 1990-91 to 4867 thousand hectares during TE 2019-20 (Table 2). Therefore, sugarcane production in India had been almost doubled i.e., from 241.05 thousand tons during TE 1990-91 to 376.91 during TE 2019-20. This was because of the increase in productivity of sugarcane during the last decade. The average yield of sugarcane in India was 65.40 tons/ha during TE 1990-91 and reached 77.60 tonnes/ha during TE 2019-20. It is visible from Fig. 1 that the area and production under sugarcane in India have been increasing over time since the 1990s in the same direction. The yield trend was almost straight line parallel to the x-axis from 1990 to 2020, except in 2003-04 where sugarcane yield was lowest 59.40 tonnes/ha recorded.

\section{Growth and instability of sugarcane in India}

The CGR of area, production, and yield of sugarcane 
in several periods in India is illustrated in Table 4. The compound growth rate of sugarcane production was 1.31 percent in India during the study period with a significant growth rate in area $(1.12 \%)$ and yield $(0.39 \%)$. The statistically significant instability in production was high at 13.73 percent than the area at $10.74 \%$ and yield $(5.26 \%)$. The annual growth rates of sugarcane production were positive and significant $(\mathrm{p} \leq 0.01)$ in period I and period IV. In contrast, period II and Period III showed a non-significant positive, and negative trend, respectively, and overall showed an increasing trend over successive periods. The increase in sugarcane production during period I and period IV wassugarcane production during period I and period IV wasto significant growth in the area under sugarcane at 1.67 percentpercent and 1.12 percent per annum, respectively. In period III, the highest yield increased significantly at CGR 1.36 percent but a non-significant decrease in area and production.

The Cuddy Della-Valle index (CDI) referred as instability index was the highest for production at 13.73 percent for period II (2000-2009) followed by area at 10.74 percent and least for the yield at 2.80 percent in period I (1990-1999). The higher value of CDI shows more instability in the area, production and yield and vice versa. The CDI in different periods varied for the area, production and yield of sugarcane in India. The area was more stable during period III, than the period I, period II and period IV overall period. However, production was found more unstable during period II than period I, period III, and the overall period, while yield was more stable in the period I as compared to period III, period II and overall period. The instability index value was less than 10 percent in the timeseries data of sugarcane (Table 4). This means that low instability was experienced in the area, production, and productivity of sugarcane in India. The study concluded that positive and significant growth occurred in production $(1.31 \%)$ and yield $(0.39 \%)$ of sugarcane for India during the study period 1990-2020. Further, there persisted extensive stability in the growth of area, production and yield of sugarcane over the study period.

\section{CONCLUSION}

The current study emphasizes spatial and instability analysis of sugarcane of major sugarcane growing states in India. The analysis results revealed that most of the states show an upward trend, and it indicates that, on average, the production of sugarcane is improved in India. The highest compound growth rates of sugarcane area and production were observed as $3.62 \%$ and $5.31 \%$, respectively, in Madhya Pradesh, while stable growth rates were experienced in Uttar Pradesh in both area and production of sugarcane. The highest CGR of yield has been recorded as $1.65 \%$ in Haryana. Low instability was experienced in the area, production, and yield of sugarcane in India. There was persisted extensive stability in the growth of the area, production, and yield of sugarcane over the study period. Thus, sugarcane plays a crucial role to fulfill the national food security mission for commercial crops.

\section{REFERENCES}

Anonymous. 2020. Agriculture Statistics at a Glance 2019, Directorate of Economics and Statistics, Government of India, https://eands.dacnet.nic.in /January, 2020.

Coppock, J.D. 1962. International Economic Instability. McGraw-Hill, New York, pp. 523-525.

Cuddy, J.D.A. and Della-Valle, P.A. 1978. Measuring the Instability of Time Series Data. Oxford Bulletin of Economics and Statistics, 40(1): 79-85.

Deb, U. and Pramanik, S. 2015. Groundnut Production Performance in Bangladesh: A District Level Analysis. Econ. Aff., 60(3): 391-400.

Dudhat, A.S., Yadav, P. and Venujayakanth, B. 2017. A Statistical Analysis on Instability and Seasonal Component in the Price Series of Major Domestic Groundnut Markets in India. Int. J. Curr. Microbiol. Appl. Sci., 6(11): 815-823.

F.A.O. 2019. OECD-FAO Agricultural Outlook 2019-2028, 5.Sugar, pp. 159.

Medar, R.A., Rajpurohit, V.S. and Ambekar A.M. 2019. Sugarcane Crop Yield Forecasting Model Using Supervised Machine Learning. Int. J. Intell. Sys. Appl., 8: 11-20.

Nimbrayan, P.K., Sunita, Bhatia, J.K. and Heena 2019. Growth and Instability in Area, Production and Productivity of Barley in Haryana vis-à-vis India. Curr. J. Appl. Sci. Technol., 35(6): 1-8.

Rahman, F. and Bee, N. 2019. Trends and Pattern of Sugarcane Production in Shahjahanpur District, Uttar Pradesh: A Geographical Analysis. Econ. Aff., 64(3): 537-545.

Rai, S.C. and Sarup, S. 1989. Statistical measures of instability in crop output. Biometrical J., 31(7): 865-873.

Raju, R. and Kumar, T.M.K. 2019. Trend Analysis of Area, Production and Productivity of Sugarcane in India. Agro Economist, 6(1): 07-13. 
$\underset{\text { AESSRA }}{\mathbb{U}}$ Singh et al.

Senapati, A.K. and Goyari, P. 2018. Agricultural Growth and Production Variability of Principal Crops in India: An Empirical Investigation. Adv. Plants Agric. Res., 8(1): 45-51.

Snehdeep, Sisodia, B.V.S., Mourya, K.K. and Rai, V.N. 2017. Trend and Growth Analysis of Rapeseed and Mustard Production in Uttar Pradesh. Int. J. Agric. Stat. Sci., 13(1): 273-277.
Sihmar, R. 2014. Growth and Instability in Agricultural Production in Haryana: A District level Analysis. Int. J. Sci. Res. Publ., 4(7): 1-12.

Yadav, R.L. and Solomon, S. 2006. Potential of Developing Sugarcane By-Product Based Industries in India. Sugar Tech., 8: 104-111. 